\title{
PENGARUH VARIASI GRADASI AGREGAT (SLAG) TERHADAP KUAT TEKAN, POROSITAS DAN KUAT TARIK BELAH BETON
}

\author{
Abd. Basid' ${ }^{1}$ Yusuf $\mathbf{W}^{2}$ \\ 1,2Jurusan Teknik Sipil Fakultas Teknik Universitas Muhammadiyah Malang \\ Alamat korespondensi : Jalan Raya Tlogomas 246 Malang 65144
}

\begin{abstract}
The use of slag as aggregate is quite reasonable because the waste slag is one that has not been exploited well, in addition to the waste in the waste, slag also categorized toxic and hazardous waste (B3). So, find the solution of the existing problems such as slag used as aggregate in concrete mixes. This research was to determine the effect of variety in slag aggregate gradations on compression strength, porosity and tensile strength of concrete side with up and down 7\% from fuller curve at 28 days. From the test result obtained by the maximum compression strength of the concrete with slag aggregate gradation that occurs at gradation III above fuller curve for 36,99 Mpa, while the maxsimum tensile strength sides also occurs in gradation III in the amount of 32,55 Mpa and for testing the minimum porosity derived porosity also occurs in gradation III is at 2,42\%. The result of testing the mechanical properties of concrete at 28 days showed that there was influence by variety in the strength of slag aggregate concrete. That the more subtle gradations on aggregate become the concrete more dense and has good quality.
\end{abstract}

Key Words : Concrete, Variety, Slag Anggregate

\begin{abstract}
Abstrak
Penggunaan slag sebagai agregat cukup masuk akal karena limbah slag adalah salah satu yang belum dimanfaatkan dengan baik, selain sampah, slag juga dikategorikan racun dan limbah berbahaya (B3). Jadi solusi dari permasalahan yang ada seperti slag digunakan sebagai agregat dalam campuran beton. Penelitian ini bertujuan untuk mengetahui pengaruh variasi dalam slag gradasi agregat slag pada kekuatan kompresi, porositas dan kekuatan tarik dari sisi beton dengan naik dan turun $7 \%$ lebih dari kurva pada 28 hari. Dari hasil pengujian diperoleh kekuatan tekan maksimum beton dengan gradasi agregat slag yang terjadi pada gradasi III di atas kurva fuller untuk 36,99 Mpa, sedangkan sisi kekuatan maxsimum tarik juga terjadi pada gradasi III sebesar 32,55 Mpa dan untuk menguji minimum porositas berasal porositas juga terjadi pada gradasi III adalah pada $2,42 \%$. Hasil pengujian sifat mekanik beton pada umur 28 hari menunjukkan bahwa ada pengaruh oleh variasi dalam kekuatan beton agregat slag. Bahwa gradasi yang lebih halus agregat menjadi beton lebih padat dan memiliki kualitas yang baik.
\end{abstract}

Kata Kunci: Beton, Campuran, Agregat slag

\section{PENDAHULUAN}

Pertumbuhan penduduk yang selalu berkembang pesat dari waktu kewaktu memaksa para ahli teknik sipil untuk terus membangun infrastruktur yang memadai, seperti pemukiman penduduk, gedung bertingkat, perkantoran, pelebaran jalan dan lain sebagainya.

Pemakaian beton sebagai bahan konstruksi Teknik Sipil, telah lama dikenal di Indonesia. Karena mempunyai kelebihan dalam mendukung tegangan tekan, mudah dibentuk sesuai kebutuhan, perawatan yang murah, dan dapat memanfaatkan bahan-bahan lokal. Oleh karena itu, beton sangat banyak dipakai dalam perencanaan struktur, baik untuk struktur skala kecil maupun besar dalam segala bentuk konstruksi sipil.

Masalah-masalah di atas menjadi pertimbangan banyak ahli teknik sipil yang mencari terobosanterobosan baru untuk mengatasi masalah tersebut, salah satunya adalah penggunaan slag.

Dengan semakin banyaknya pemakai beton di dalam industri kontruksi maka semakin banyak pula usaha untuk memperbaiki mutu beton, salah satu cara untuk memperbaiki mutu beton adalah dengan memanfaatkan limbat slag sebagai agregat kasar. 
Penggunaan slag yang merupakan hasil limbah peleburan baja sampai saat ini di Indonesia masih belum dimanfaatkan dengan baik, selain merupakan limbah yang terbuang, slag juga dikategori limbah bahan beracun dan berbahaya (B3).

Penggunaan slag dalam campuran beton dapat memberikan keuntungan diantaranya adalah menghemat biaya produksi, mengurangi limbah yang ada di jawa timur khususnya limbah baja serta mengurangi pencemaran lingkungan, dari hasil penelitian sebelumnya menunjukkan bahwa penggunaan slag sebagai bahan tambah ini menaikkan kuat tekan beton (vena, zumi.2006), maka dari itu untuk penelitian yang akan kami lakukan adalah mengganti semua agregat yang ada pada beton dengan slag sesuai dengan jenis gradasinya.

Ada beberapa fakta yang mempengaruhi kekuatan yaitu :

\section{Faktor Air Semen ( FAS )}

Tri mulyono (2004:12) Secara umum, semakin besar nilai FAS semakin rendah mutu kekuatan beton. Dengan demikian untuk menghasilkan sebuah beton yang bermutu tinggi FAS dalam beton haruslah rendah, sayangnya hal ini menyebabkan kesulitan dalam pengerjaan. Umumnya nilai FAS minimum untuk beton normal sekitar 0,4 dan nilai maksimal 0,65.

Tujuan pengurangan FAS ini adalah untuk mengurangi hingga seminimal mungkin porositas beton yang dibuat sehingga akan dihasilkan beton mutu tinggi. Pada beton mutu tinggi atau sangat tinggi, Supartono (1998:75) FAS dapat diartikan sebagai meter to comentious ratio, yaitu berat air terhadap berat total semen dan aditif comentious yang umumnya di tambahkan pada campuran beton mutu tinggi.

\section{Kualitas Agregat}

Menurut Larrad (1990:112), Umumnya agregat halus mempunyai modulus halus butiran (MHB) sekitar 1,50-3,8. Hasil penelitian menunjukkan bahwa nilai $2,5<\mathrm{MHB}<3,0$ umumnya menghasilkan beton mutu tinggi dengan FAS yang rendah dan mempunyai kekuatan tekan dan kelecakan yang optimal. Ukuran butir agregat maksimum juga akan mempengaruhi mutu beton yang akan dibuat. Hasil penelitian Larrad (1990:118) menyebutkan bahwa butiran maksimum yang memberikan arti nyata untuk membuat beton mutu tinggi tidak boleh lebih dari $15 \mathrm{~mm}$. Namun demikian pemakaian butiran agregat sampai dengan $25 \mathrm{~mm}$ masih memungkinkan di perolehnya beton mutu tinggi dalam proses produksinya.

\section{Bahan Tambah}

Pengurangan kadar air dalam pembuatan beton menjadi perhatian penting. Dengan bahan tambahan yang dapat mengurangi air sangat tinggi seperti superplasticizer diharapkan kekuatan beton yang dihasilkan lebih tinggi dengan air yang sedikit, tetapi tingkat kemudahan pekerjaan juga lebih tinggi, penggunaannya disesuaikan dengan standart ASTM C 494 type F.

\section{Kontrol Kualitas}

Untuk menghasilkan beton yang bermutu tinggi, faktor kontrol terhadap kualitas proses produksi beton pada saat pengambilan sampel, pengujian maupun proses penakaran sampai perawatan mutlak menjadi perhatian penting.

Beton merupakan campuran antara semen, agregat halus, agregat kasar dan air dengan atau tanpa bahan tambahan membentuk massa padat. menurut Nawy (1985:8) beton merupakan sekumpulan interaksi mekanis dan kimiawi dari material pembentuknya.

Perbandingan Volume antara agregat dan semen berkisar antara 6 sampai dengan 10. Dan faktor air semen atau fas 0,35 sampai dengan 0,45. Perkisaran faktor air semen tidak terlalu besar karena jika faktor air semen terlalu rendah maka pasta semen tidak cukup menyelimuti butiran-butiran agregat kasar, dan bila faktor air semen terlalu besar maka pasta semen terlalu encer sehingga pada waktu pemadatan pasta semen mengalir kebawah (tidak lagi menyelimuti butir-butir semen)

\section{Sifat Fisik Semen}

\section{- Kehalusan Semen}

Reaksi antara semen dam air dimulai dari permukaan butir-butir semen, sehingga makin luas permukaan butir-butir semen (dari berat semen yang sama) makin cepat proses 
hidrasinya. Hal ini berarti bahwa, butiran-butir semen yang halus akan menjadi kuat dan menghasilkan panas hidrasi yang lebih cepat dari pada semen dengan butir-butir yang lebih kasar. Kehalusan semen menurut SII 0013 81 , paling sedikit $90 \%$ berat semen harus dapat lewat ayakan lubang $0,90 \mathrm{~mm}$. namun perlu dicatat, bahwa jika butir-butir semen terlalu halus, sifat semen akan akan menjadi kebalikannya, karena terjadi hidrasi awal oleh kelembaban udara. (Tjokrodimulyo, 1996)

- $\quad$ Reaksi Hidrasi

Ketika air ditambahkan kedalam campuran semen, proses kimiawi yang disebut hidrasi akan berlangsung. Senyawa kimia di dalam semen akan bereaksi dengan air dan membentuk komponen baru.

Mekanisme hidrasi semen ada dua, yaitu mekanisme larutan dan mekanisme padat. Pada mekanisme larutan, zat yang direaksikan larut dan menhhasilkan ion dalam larutan. Ionion ini kemudian akan bergabung sehingga menghasilkan zat yang mengumpal (flocculate). Pada semen, karena daya larut senyawa yang ada kecil maka hidrolisis lebih dominan dari pada larutan.

- Waktu Pengerasan Semen

Jikan semen dicampur dengan air membentuk bubur yang secara bertahap menjadi kurang plastis, dan akhirnya menjadi keras. Pada proses ini tahap pertama dicapai ketika pasta semen cukup kaku untuk menahan suatu tekanan, tehap ini disebut sebagai waktu ikat. Waktu ikat dibagi menjadi dua bagian yaitu waktu ikat awal (initial time) yatu waktu awal dari pencampuran semen dan air sampai saat kehilangan sifat keplastisannya, dan waktu ikat akhir (final setting time) waktu sampai mencapai pasta semen menjadi massa yang keras (Tjokrodimulyo, 1996).

Sebenarnya pengikatan awal lebih penting, yaitu saat semen terkena air hingga mulai terjadi pengikatan (pengerasan), biasanya digunakan alat vikat untuk mengukur waktu pengerasan. Bagi jenis-jenis semen Portland waktu pengikatan awal tidak boleh kurang dari 60 menit sejak semen terkena air (Wuryati $S$ dan Candra $R, 2001)$.

- Panas Hidrasi
Panas hidrasi adalah reaksi membentunya media perekat antara silikat dan aluminat pada semen bereaksi dengan air menjadi perekat yang memadat lalu membentuk massa yang keras. Hidrasi bersifat eksotermis dengan panas yang dikeluarkan kira-kira 110 kalori/ gram sampai pada tujuh hari pertama, dan 70 kalori/gram sampai pada 28 hari.

Panas hidrasi naik sesuai dengan ketinggian temperature pada saat hidrasi terjadi. Untuk semen biasa panas hidrasi tersebut bervariasi antara $37 \mathrm{kalori} /$ gram pada $5^{\circ} \mathrm{C}$ sampai dengan $80 \mathrm{kalori} /$ gram pada $40^{\circ} \mathrm{C}$. untuk semua jenis semen pada umumnya kira-kira $60 \%$ dari panas total dibebaskan pada waktu antara 1 dan 3 hari pertama, kira-kira 80\% sampai hari ketujuh, dan antara 90-95\% dalam jangka waktu 6 bulan. Laju perubahan panas tergantung pada komposisi semen. Laju hidrasi dan perubahan panas bertambah besar sejalan dengan semakin halusnya semen. Walaupun kualitas total panas yang dibebaskan tidak dipengaruhi oleh kehalusan tersebut.

- Berat Jenis dan Berat

Berat jenis semen dari semen pada umumnya berkisar antara 3,10 sampai 3,30, berat jenis rata-rata digunakan 3,15 , dan berat isi (berat satuan) semen sangat tergantung pada cara pengisian semen ke dalam takaran. Jika pengisian dipadatkan, berat isinya dapat mencapai $1,5 \mathrm{~kg} /$ liter. Dalam praktek biasanya dipakai berat isi rata-rata yaitu antara $1,25 \mathrm{~kg} /$ liter (Wuryati S dan Candra R, 2001).

\section{Jenis-jenis semen Portland}

Sesuai dengan pemakaiannya, semen Portland di Indonesia (PUBI-1982) dibagi menjadi 5 jenis. Adapun jenis-jenis semen tersebut adalah :

- Jenis I : Semen Portland untuk penggunaan umum yang tidak memerlukan persyaratanpersyaratan khusus seperti yang disyaratkan pada jenis-jenis lain

- Jenis II : Semen Portland yang dalam penggunaannya, memerlukan ketahanan sulfat dan panas hidrasi sedang

- Jenis III : Semen Portland yang dalam pengunaannya, menuntut persyaratan kekuatan awal yang tinggi. 
- Jenis IV : Semen Portland yang dalam pengunaannya, menuntut persyaratan panas hidrasi yang rendah.

- Jenis V : Semen Portland yang dalam pengunaannya, menuntut persyaratan sangat tahan terhadap sulfat

\section{Agregat}

Agregat adalah butiran mineral yang merupakan hasil disintegrasi alami batuan-batuan atau juga berupa hasil mesin pemecah batu dengan memecah batu alami. Agregat merupakan salah satu bahan pengisi pada beton, namun demikian peranan agregat pada beton sangatlah penting. Kandungan agregat dalam beton kira-kira mencapai 70\% - 75\% dari volume beton. Agregat sangat berpengaruh terhadap sifat-sifat beton, sehingga pemilihan agregat merupakan suatu bagian penting dalam pembuatan beton.

Agregat dibedakan menjadi dua jenis, yaitu agregat halus dan agregat kasar. Cara membedakan jenis agregat yang paling banyak dilakukan adalah berdasarkan ukuran butiran-butirannya. Agregat halus adalah pasir alam sebagai disintegrasi alami dari batuan atau pasir yang dihasilkan oleh industry pemecah batu dan mempunyai ukuran terbesar 4,8 mm. (Tjokrodimulyo, 1992)

Kekuatan beton tidak lebih tinggi daripada kekuatan agregatnya. Oleh karena itu sepanjang kuat tekan agregat lebih tinggi daripada beton yang dibuat dari agregat tersebut maka agregat tersebut masih dianggap cukup kuat. Kekuatan dan sifat lain dari agregat dapat sangat bervariasi dalam batasbatas yang besar. Butir-butir agregat dapat bersifat kurang kuat karena dua sebab, yaitu Karena terdiri dari bahan yang lemah atau terdiri dari partikelpartikel yang kuat tetapi tidak terikat dengan kuat, jadi bahan ikatnya yang kurang kuat.

Cara untuk menguji kekuatan agregat kasar ialah dengan alat uji derak Los Angeles. Pada cara uji ini contoh butir-butir agregat dimasukkan ke dalam silinder logam, dengan bola-bola baja untuk memukul, kemudian silinder diputar sehingga butirbutir agregat tersebut terpukul-pukul dan terabrasi. Prosentase jumlah berat agregat yang hancur selama pengujian merupakan ukuran dari sifat-sifat agregat, yaitu keuletan, kekerasan, dan ketahanan aus, yang diharapkan merupakan sifat langsung yang berhubungan dengan kekuatan. Pengujian cara derek Los Angeles ini tampak memuaskan jika dipakai untuk menguji agregat normal dan agragat berat. Cara uji derek ini juga dapat digunakan untuk memeriksa banyaknya butiran yang pecah pada akhir putaran ke-100 kali yang pertama dibandingkan dengan pada akhir butiran ke-500. Umumnya jika butiran yang pecah pada akhir putaran ke-100 sudah lebih dari 20 persen dari pada akhir ke-500 dianggap bagian butir yang lunak sudah terlalu banyak.

Dengan Mengacu pada permasalahan di atas maka dibuat rumusan masalah sebagai berikut :

- $\quad$ Bagaimana pengaruh variasi gradasi agregat slag sebagai pengganti agregat terhadap kuat tekan beton?

- Bagaimana pengaruh variasi gradasi agregat slag sebagai pengganti agregat terhadap porositas beton?

- $\quad$ Bagaimana pengaruh variasi gradasi agregat slag sebagai pengganti agregat terhadap kuat tarik belah beton?

Adapun Tujuan Penelitian ini aadalah sebagai berikut :

- Untuk mengetahui pengaruh variasi gradasi agregat slag sebagai pengganti agregat terhadap kuat tekan beton.

- Untuk mengetahui pengaruh variasi gradasi agregat slag sebagai pengganti agregat terhadap porositas beton.

- Untuk mengetahui pengaruh variasi gradasi agregat slag sebagai pengganti agregat terhadap kuat tarik belah beton.

Tabel 1. syarat mutu kekuatan agregat sesuai dengan SII.0052-80

\begin{tabular}{cccc}
\hline \multirow{2}{*}{ Kelas Dan Mutu Beton } & $\begin{array}{c}\text { Kekerasan dengan bejana rudelloff, } \\
\text { bagian hancur menembus ayakan 2 mm, } \\
\text { persen (\%) maksimum }\end{array}$ & $\begin{array}{c}\text { Kekerasan dengan bejana } \\
\text { gesek Los Angelos } \\
\text { bagian yang hancur } \\
\text { menembus ayakan 1,7 } \\
\text { mm \% maks }\end{array}$ \\
\cline { 2 - 3 } & $\begin{array}{c}\text { Fraksi Butiran } \\
9,5-19 \mathrm{~mm}\end{array}$ & $\begin{array}{c}\text { Fraksi Butiran } \\
\text { mm }\end{array}$ & $(3-30$ \\
\hline Beton Kelas I dan mutu $\mathrm{B}_{0}$ dan $\mathrm{B}_{1}$ & $(2)$ & $24-32$ & $(4)$ \\
\hline
\end{tabular}




\begin{tabular}{lccc}
\hline $\begin{array}{l}\text { Beton Kelas II dan mutu K.125, K.175 } \\
\text { dan K.225 }\end{array}$ & $14-22$ & $16-24$ & $27-40$ \\
$\begin{array}{l}\text { Beton Kelas III dan mutu }>\text { K }>225 \\
\text { atau beton pratekan }\end{array}$ & Kurang dari 14 & Kurang dari 16 & Kurang dari 27 \\
\hline
\end{tabular}

\section{METODE PENELITIAN}

Dalam melakukan penelitian atau Research diperlukan suatu tempat penelitian untuk memperoleh data - data yang mendukung tercapainya tujuan penelitian. Pembuatan benda uji berupa beton silinder dilaksanakan di Laboratorim Beton Universitas Muhammadiyah Malang dan proses pengujian bahan, , dilaksanakan di Laboratorium Beton Universitas Muhammadiyah Malang Jurusan Teknik Sipil.

Dalam penelitian ini dilakukan 3 jenis variasi gradasi, dimana setiap variasi terdiri dari 9 benda uji. Adapun variasi gradasi yang direncanakan adalah dengan up and down 7\% dari kurva fuller seperti kurva berikut :

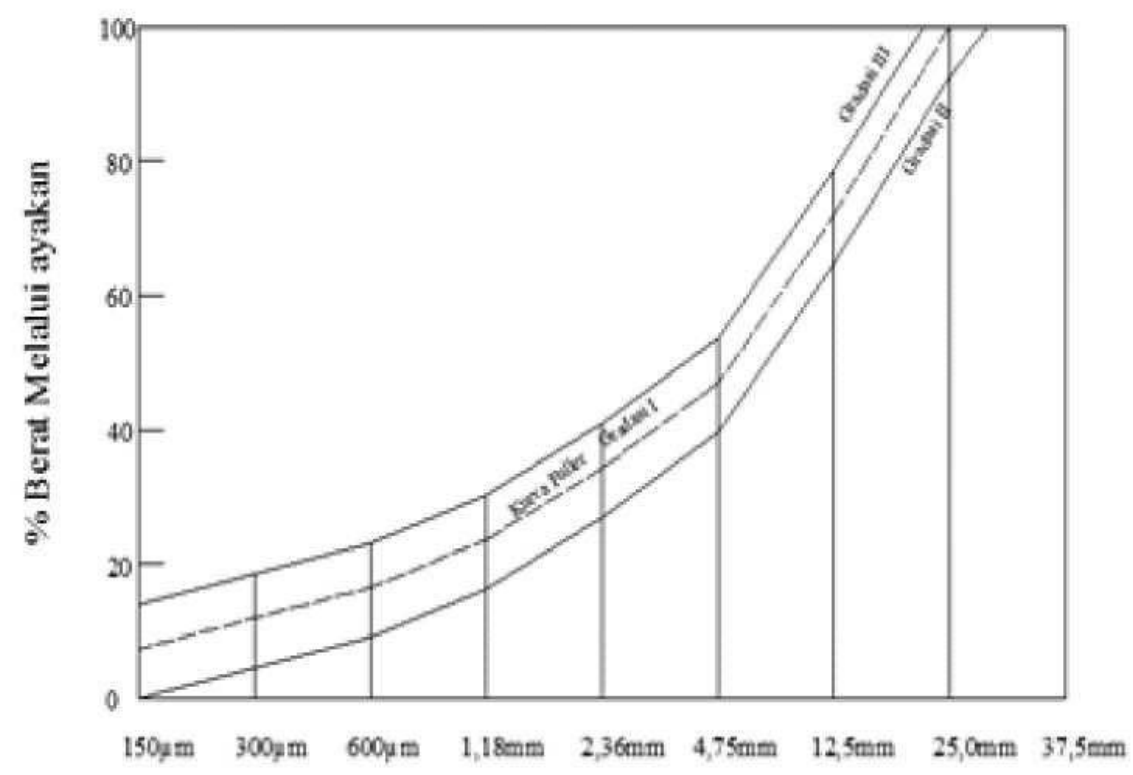

Ukuran Ayakan

Gambar 1. Rencana Variasi Gradasi Dengan Kurva Fuller

Tabel 2 Proporsi Campuran Beton

\begin{tabular}{|c|c|c|c|c|c|}
\hline $\begin{array}{r}\text { Gradasi } \\
(\mathrm{Pe}\end{array}$ & $\begin{array}{l}\text { Fuller } \\
\text { I) }\end{array}$ & $\begin{array}{r}\mathrm{G} \\
(\mathrm{Per}\end{array}$ & II & \multicolumn{2}{|c|}{$\begin{array}{c}\text { Gradasi III } \\
\text { (Percobaan III) }\end{array}$} \\
\hline \multicolumn{6}{|c|}{ Agregat Halus } \\
\hline $1,18 \mathrm{~mm}$ & $2,36 \mathrm{~mm}$ & $1,18 \mathrm{~mm}$ & $2,36 \mathrm{~mm}$ & $1,18 \mathrm{~mm}$ & $2,36 \mathrm{~mm}$ \\
\hline $73 \%$ & $27 \%$ & $72 \%$ & $28 \%$ & $55 \%$ & $45 \%$ \\
\hline \multicolumn{6}{|c|}{ Agregat Kasar } \\
\hline \multicolumn{2}{|c|}{ Gradasi I Kurva Fuller } & \multicolumn{2}{|c|}{ Gradasi II } & \multicolumn{2}{|c|}{ Gradasi III } \\
\hline $4,74 \mathrm{~mm}$ & $12,5 \mathrm{~mm}$ & $4,74 \mathrm{~mm}$ & $12,5 \mathrm{~mm}$ & $4,74 \mathrm{~mm}$ & $12,5 \mathrm{~mm}$ \\
\hline $75 \%$ & $25 \%$ & $62 \%$ & $38 \%$ & $47 \%$ & $53 \%$ \\
\hline
\end{tabular}

\section{Tahapan Penelitian}

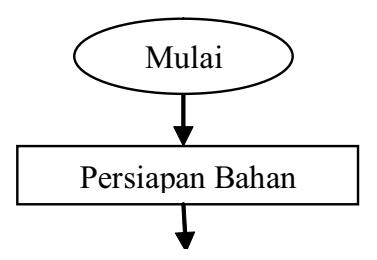




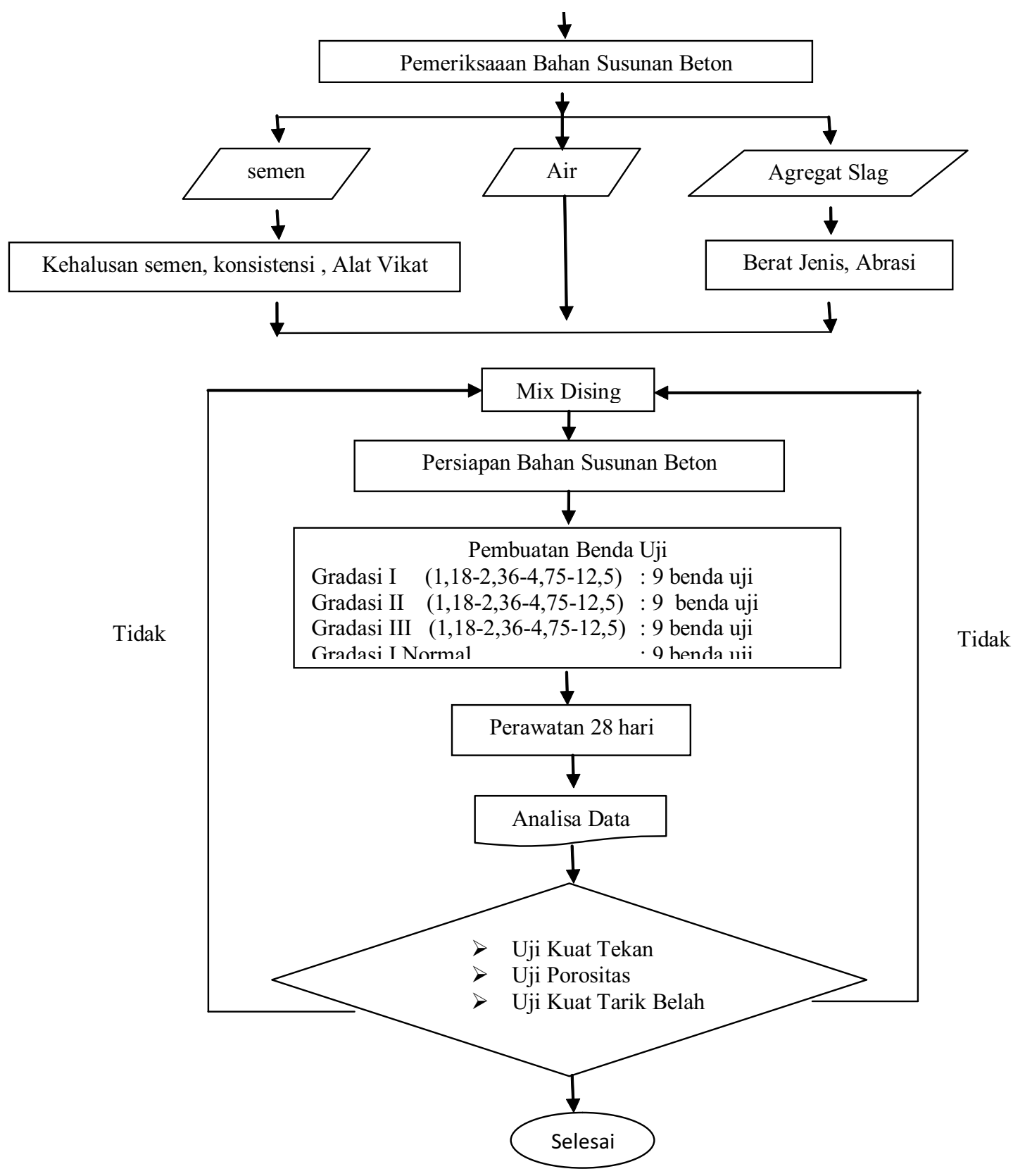

Gambar 2. Tahapan Penelitian

Tabel 3. Rancana Gradasi Campuran Beton

\begin{tabular}{cccccc}
\hline \multicolumn{2}{c}{$\begin{array}{c}\text { Gradasi I Kurva Fuller } \\
\text { (Percobaan I) }\end{array}$} & \multicolumn{2}{c}{$\begin{array}{c}\text { Gradasi II } \\
\text { (Percobaan II) }\end{array}$} & $\begin{array}{c}\text { Gradasi III } \\
\text { (Percobaan III) }\end{array}$ \\
\hline \multicolumn{7}{c}{ Agregat Halus } \\
\hline $1,18 \mathrm{~mm}$ & $2,36 \mathrm{~mm}$ & $1,18 \mathrm{~mm}$ & $2,36 \mathrm{~mm}$ & $1,18 \mathrm{~mm}$ & $2,36 \mathrm{~mm}$ \\
$73 \%$ & $27 \%$ & $72 \%$ & $28 \%$ & $55 \%$ & $45 \%$ \\
$10,2711 \mathrm{~kg}$ & $3,7989 \mathrm{~kg}$ & $10,1304 \mathrm{~kg}$ & $3,9396 \mathrm{~kg}$ & $7,722 \mathrm{~kg}$ & $6,348 \mathrm{~kg}$ \\
\hline \multicolumn{7}{c}{ Agregat Kasar } \\
\hline \multicolumn{2}{c}{ Gradasi I Kurva Fuller } & \multicolumn{2}{c}{ Gradasi II } & \multicolumn{2}{c}{ Gradasi III } \\
\hline $4,74 \mathrm{~mm}$ & $12,5 \mathrm{~mm}$ & $4,74 \mathrm{~mm}$ & $12,5 \mathrm{~mm}$ & $4,74 \mathrm{~mm}$ & $12,5 \mathrm{~mm}$ \\
$75 \%$ & $25 \%$ & $62 \%$ & $38 \%$ & $47 \%$ & $53 \%$ \\
$19,605 \mathrm{~kg}$ & $6,535 \mathrm{~kg}$ & $16,2068 \mathrm{~kg}$ & $9,9332 \mathrm{~kg}$ & $12,2858 \mathrm{~kg}$ & $13.8542 \mathrm{~kg}$ \\
\hline \multicolumn{7}{r}{} \\
\hline
\end{tabular}




\section{HASIL DAN PEMBAHASAN}

\section{Kuat Tekan Beton}

Dari hasil penelitian kuat tekan beton dengan menggunakan anggregat slag dengan memainkan gradasi fuller untuk gradasi I dengan ukuran agregat $1,18 \mathrm{~mm}=73 \%, 2,36 \mathrm{~mm}=27 \%, 4,74 \mathrm{~mm}=$ $75 \%$ dan $12,5 \mathrm{~mm}=25 \%$ didapat kuat tekan beton sebesar 35,48 MPa sedangkan kontrolnya yaitu beton normal dengan gradasi yang sama sebesar $30,20 \mathrm{MPa}$.

Untuk gradasi II yaitu dibawah kurva fuller dengan ukuran agregat $1,18 \mathrm{~mm}=72 \%, 2,36 \mathrm{~mm}=$ $28 \%, 4,74 \mathrm{~mm}=62 \%$ dan $12,5 \mathrm{~mm}=38 \%$ terdapat penurunan kuat tekan beton sebesar 33,22 MPa atau $6,37 \%$ dari beton dengan gradasi I fuller.

Untuk gradasi III dengan ukuran agregat $1,18 \mathrm{~mm}=55 \%, 2,36 \mathrm{~mm}=45 \%, 4,74 \mathrm{~mm}=47 \%$ dan $12,5 \mathrm{~mm}=53 \%$ memberikan peningkan kuat tekan beton sebesar 36,99 MPa atau 4,26\% dari beton dengan gradasi I fuller.

Dari hasil pengujian kuat tekan beton pada umur 28 hari menunjukkan bahwa ada pengaruhnya dengan variasi agregat slag dengan kuat tekan beton. Bahwa semakin banyak agregat dengan gradasi halus maka beton semakin padat dan memiliki kuat tekan yang tinggi.

\section{Kuat Tarik Belah}

Dari hasil penelitian kuat tarik belah beton dengan menggunakan anggregat slag dengan memainkan gradasi fuller untuk gradasi I dengan ukuran agregat $1,18 \mathrm{~mm}=73 \%, 2,36 \mathrm{~mm}=27 \%$, $4,74 \mathrm{~mm}=75 \%$ dan $12,5 \mathrm{~mm}=25 \%$ memberikan peningkan kuat tarik belah beton sebesar 27,36 MPa sedangkan kontrolnya yaitu beton normal dengan gradasi yang sama sebesar 24,53 MPa .

Untuk gradasi II dengan ukuran agregat $1,18 \mathrm{~mm}=72 \%, 2,36 \mathrm{~mm}=28 \%, 4,74 \mathrm{~mm}=62 \%$ dan $12,5 \mathrm{~mm}=38 \%$ terdapat penurunan kuat tarik belah beton sebesar 25,48 MPa atau $6,87 \%$ dari beton dengan gradasi I fuller.

Untuk gradasi III dengan ukuran agregat $1,18 \mathrm{~mm}=55 \%, 2,36 \mathrm{~mm}=45 \%, 4,74 \mathrm{~mm}=47 \%$ dan $12,5 \mathrm{~mm}=53 \%$ memberikan peningkan kuat tarik belah beton sebesar $32,55 \mathrm{MPa}$ atau $18,97 \%$ dari beton dengan gradasi I fuller.
Dari hasil pengujian kuat tarik belah beton pada umur 28 hari menunjukkan bahwa ada pengaruhnya dengan variasi agregat slag dengan kuat tarik belah beton. Bahwa semakin padat beton tersebut maka semakin besar kuat tarik belahnya.

\section{Porositas Beton}

Dari hasil penelitian porositas beton dengan menggunakan anggregat slag dengan memainkan gradasi fuller untuk gradasi I dengan ukuran agregat $1,18 \mathrm{~mm}=73 \%, 2,36 \mathrm{~mm}=27 \%, 4,74 \mathrm{~mm}=$ $75 \%$ dan $12,5 \mathrm{~mm}=25 \%$ didapat porositas beton sebesar 2,46\% sedangkan kontrolnya yaitu beton normal dengan gradasi yang sama sebesar 2,77\% $\mathrm{kg} / \mathrm{cm}^{2}$.

Untuk gradasi II yaitu dibawah kurva fuller dengan ukuran agregat $1,18 \mathrm{~mm}=72 \%, 2,36 \mathrm{~mm}=$ $28 \%, 4,74 \mathrm{~mm}=62 \%$ dan $12,5 \mathrm{~mm}=38 \%$ terdapat kenaikan porositas beton sebesar 2,51\% atau 2,03\% dari beton dengan gradasi I fuller.

Untuk gradasi III dengan ukuran agregat $1,18 \mathrm{~mm}=55 \%, 2,36 \mathrm{~mm}=45 \%, 4,74 \mathrm{~mm}=47 \%$ dan $12,5 \mathrm{~mm}=53 \%$ memberikan penurunan porositas beton sebesar $2,42 \%$ atau $1,63 \%$ dari beton dengan gradasi I filler.

Dari hasil pengujian porositas beton pada umur 28 hari menunjukkan bahwa ada pengaruhnya dengan variasi agregat slag terhadap porositas beton. Bahwa semakin padat beton tersebut maka semakin kecil porositasnya.

\section{KESIMPULAN DAN SARAN}

\section{Kesimpulan}

- Rancangan campuran beton agregat normal diperoleh perbandingan $1: 1,22: 2,26$ sedangkan dengan agregat slag diperoleh $1: 2: 2,41$ memiliki pengaruh siqnifikan terhadap adanya variasi gradasi agregat slag terhadap Kuat tekan yaitu terjadi pada gradasi III dengan proporsi campuran agregat slag $1,18 \mathrm{~mm}=$ $55 \%, 2,36 \mathrm{~mm}=45 \%, 4,74 \mathrm{~mm}=47 \%$ dan $12,5 \mathrm{~mm}=53 \%$ memberikan 1 .

peningkan kuat tekan sebesar 36,99 MPaatau $6,37 \%$ dari gradasi I fuller itu disebabkan karena pada gradasi III campuran agregat slag hampir mendekati $50 \%$ pada setiap gradasinya 
sehingga beton menjadi padat dan sedikit menyerap air serta rongga udara yang kecil.

- $\quad$ Pengaruh variasi gradasi agregat slag terhadap kuat tarik belah beton tertinggi terjadi pada gradasi III dengan proporsi campuran agregat slag $1,18 \mathrm{~mm}=55 \%, 2,36 \mathrm{~mm}=45 \%, 4,74 \mathrm{~mm}$ $=47 \%$ dan $12,5 \mathrm{~mm}=53 \%$ memberikan peningkan kuat tarik belah sebesar $32,55 \mathrm{Kg} /$ $\mathrm{cm}^{2}$ atau $18,97 \%$ dari gradasi I fuller, hal ini karena disebabkan pada gradasi III agregat halus dan kasarnya hampir seimbang sehingga tersusun padat dan memiliki rongga udara yang kecil bahkan mungkin mendekati 0 .

- Adanya pengaruh variasi gradasi terhadap Porositas beton yaitu terendah terjadi pada gradasi III dengan proporsi campuran agregat slag $1,18 \mathrm{~mm}=55 \%, 2,36 \mathrm{~mm}=45 \%, 4,74 \mathrm{~mm}$ $=47 \%$ dan $12,5 \mathrm{~mm}=53 \%$ memberikan peningkan kuat tarik belah sebesar 2,42\%atau $1,63 \%$ dari gradasi I fuller. Hal ini disebabkan karena beton dengan variasi gradasi agegat slag mengurangi penyerapan air serta agregat dalam beton tersusun padat sehingga memiliki kerapatan gradasi campuran beton baik.

\section{Saran}

- Diharapkan penelitian ini dapat dikembangkan pada penelitian selanjutnya dengan memanfaatkan slag sebangai agregat untuk beton mutu tinggi dengan penambahan zat additive seperti silica fume dan zat additive lainnya, agar didapat kuat tekan yang optimum.

- Untuk penelitian berikutnya mix design untuk agregat slag diusahakan memakai mix design yang sesuai dengan berat jenis slag.

- $\quad$ Perlu adanya pengkajian ulang tentang mix design dengan agregat slag, sehingga menghasilkan campuran beton yang sesuai dengan bahan yang digunakan sehingga mendapatkan kuat takan yang maksimal.

- $\quad$ Pengujian untuk beton dengan agregat slag untuk penelitian selanjutnya diharapakan umur beton diatas 28 hari.

\section{DAFTAR PUSTAKA}

Anonim, Persyaratan Umum Bahan Bangunan Di Indonesia (PUBI).Pusat Penelitian dan
Pengembangan Pemukiman, badan peneliti dan pengembangan. DPU, 1982

Anonim, Buku petunjuk Praktikum Teknologi Beton. Universits Muhammadiyah Malang

Ali Achmadi, 2009. Kajian Beton Mutu Tinggi Menggunakan Slag Sebagai Agregat Halus Dan Agregat Kasar Dengan Aplikasi Superplasticizer dan Silicafume.Tesis. Fakultas Teknik, Universitas Diponegoro

Donal W Lewis, 1982.Properties And Uses Of Iron And Steel Slag. NSA Presented a Symposium

Dewi Dwirianti, 2008.Solidifikasi Dan Stabilisasi Steel Slag Serta Pemanfaatannya Sebagai Fine Aggregate.Research.Surabaya : ITS (http://digilib.its.ac.id/solidifikasi-dan-stabilisasisteel-slag-serta-pemanfaatannya-sebagai-fineaggregate-1840.html)

Departemen Pekerjaan Umum. 2005. Pedoman penggunaan slag besi dan baja untuk Campuran beraspal panas. Pd-T 04-2005. Jakarta: Departemen Pekerjaan umum

Dipohusodo, Istimawan, 1994. Struktur beton bertulang : Jakarta : PT. Gramedia Pustaka Utama.

Mulyono,Tri,Ir,MT, Teknologi Beton, Andi Yogjakarta,2004

Neville, Brooks, 1987. Concrete Teknologi, Longman Scientifie and Technical. New York

Nawi, G. 1985. Beton Bertulang Suatu Pendekatan Dasar. Bandung : PT Eresco

Patel, Jigar P, 2008. Broader Use of Steel Slag Aggregates in Concrete Author. Bachelor Of Science In Civil Enggineering, Maharaja Sayajirao University Of Baroda. India

Paul Nugraha, Antoni, Teknologi Beton, Andi Surabaya, 2007

Supartono, 1998. Mix design for high strength concrete using Indonesian materials, "Second Asia-Pacific Concrete Technology Conference", Institute for International Research (IIR). Jakarta

SNI 62-1990-03, Departement Pekerjaan Umum," Metode Pembuatan dan Perawatan Benda Uji Beton di Laboratorium

SNI 03-6826-2002, Metode Pengujian Konsistensi Normal Semen Portland dengan Alat Vicat untuk Pekerjaan Teknik Sipil 
SNI 03-6827-2002, Metode Pengujian Waktu Ikat Awal Semen Portland dengan Alat Vicat untuk Pekerjaan Teknik Sipil

Tjokrodimulyo, Kardiyono, 1992. Teknologi Beton. Yogyakarta : UGM 